\title{
Santeri Nuorteva and the Origins of Soviet-American Relations
}

\author{
By Auvo Kostiainen
}

University of Turku

The growing radical movements in Tsarist Russia at the turn of the century produced many international revolutionaries who aroused tension and fear not only in their own country, but also in other countries where they worked for the revolution in Russia. At the turn of the century Finland was a part of the Russian empire, having been taken from Sweden in the beginning of the nineteenth century. Particularly during the late nineteenth and early twentieth century the Russian Grand Duchy of Finland was heavily oppressed by the Tsarist government, and its special rights as a part of the empire were being restricted.

Santeri Nuorteva (originally Alexander Nyberg, and in his later years in The Soviet Union Alexander Fedorovitch Nuorteva) was a product of these circumstances. Born in 1881 in Viipuri, his father was of FinnishSwedish and his mother of Russian Jewish background. Nuorteva's international background had an effect on his future life, particularly on his linguistic capabilities (it is said that in his late years Nuorteva could speak more than ten languages) and his contacts with Russia. In this article special attention is paid to Santeri Nuorteva's important role in the development of the early connections between the United States and the Soviet Union, or Soviet Russia, as it was called during the years following the October revolution.' The article is based mainly on archival and documentary sources from Finland, the United States and the Soviet Union. A special difficulty always exists when archival sources are used to study international radicals like Nuorteva: many sources have been destroyed deliberately. Many of the international revolutionaries' activities were illegal and therefore undocumented. Moreover, in many cases government information contains numerous errors that derive from a number of sources. ${ }^{2}$

Historians have shown little interest in Nuorteva's career, perhaps because of the elusiveness of a restless life marked by frequent moves from one country to another. Apart from some biographies loaded with misunderstandings and errors, there are no scholarly studies. Although 
many studies on international affairs or radical movements have paid some attention to his activities, work on Santeri Nuorteva has proved to be pioneering research on a notable and colourful individual. ${ }^{3}$

Nuorteva came from a family that had made a distinguished contribution to the cultural life of Finland. At the beginning of the century Nuorteva joined the Social-Democratic movement and soon became a leading member of the Party and a member of Parliament. The period was one of great political unrest with recurring dissolutions of Parliament that resulted from the rapidly increasing pressure of Russia on Finland. In the year 1909 Nuorteva was sentenced to six months in prison for lese-majesty. This was due to the publication of writings critical of the Tsar in a newspaper which he edited. When in the course of 1911 it seemed clear that he could expect a further sentence for a similar crime, Nuorteva found it prudent to leave for the United States, as many other Finnish socialists had done.

In the United States, Santeri Nuorteva quickly established himself as one of the leaders of the Finnish-American socialists and their very active organization Yhdysvaltain Suomalainen Sosialistijärjestö (Finnish Socialist Federation, FSF). He worked there as an editor of the Finnish-language workingmen's journals Toven'(Comrade), Raivaaja (Pioneer) and Sakenia (Sparks), and as an active functionary and lecturer of the Finnish Socialist Federation. Thanks to his linguistic capabilities and to the fact that he was a very representativefigure - he had experienced after all a significant political career in Finland - Nuorteva also became the representative of the Finnish-American socialists in their dealings with the Socialist Party of America. But it was not until the beginning of 1918 that Nuorteva acquired real notoriety when he was asked by Yrjo Sirola of the Finnish Red revolutionary government to be their representative in the United States.

Nuorteva agreed and became particularly active in propaganda work, circulating articles which described the Finnish situation to American organizations and which reached even people in the government. So successful was he in his task that he managed to embarrass the representatives of the official »White « Finnish government by getting their accounts in New York banks frozen.

The main argument employed by Nuorteva was that White Finland was an ally of Germany and a defender of German interests. Since the United States had already in the spring of 1917 joined the Allies in the war against the central Powers, Nuorteva did not find it difficult to get public opinion on his side. He sent propaganda material and many letters to representatives of the United States government in Washington, 
even to President Woodrow Wilson. Information was continuously sent to large newspapers like the New York Times, the New York Tribune, the Evening Post and many others. ${ }^{4}$

From the beginning, Nuorteva linked the Finnish and Russian revolutions in his propaganda. When he and his Finnish Information $\mathrm{Bu}$ reau, which he established in New York on March 30, 1918, issued propaganda for the Finnish revolutionary government, they included on ,their own initiative propaganda for the Russian Bolshevik cause. This became apparent in the numerous meetings organized by Nuorteva. For example, in May 1918 in New York's Carnegie Hall, a mass meeting with about $\mathbf{3 0 0 0}$ participants - most of them Americans - was held. In the meeting, in addition to Santeri Nuorteva, certain leading American radicals spoke, such as the prominent socialist Morris Hillquit, who also happened to be the legal adviser of Nuorteva's Finnish Information Bureau. John Reed, the well-known leftist writer, also delivered a speech. The speakers demanded that the United States government recognize both the Russian and Finnish revolutionary governments. ${ }^{5}$

As the Red revolution in Finland lost momentum during the spring of 1918 and was finally defeated in May of 1918, Nuorteva's role in the United States increasingly became that of a defender of Soviet Russia. He was in contact with various organizations and individuals sympathetic to the Bolsheviks, and by working with them he engaged in propaganda activity for the Soviet Russian cause. From the reports and reminiscences of Nuorteva, however, it is clear that the Bolshevik government did not give him direct orders or financial support at this stage. He initiated his activities himself. ${ }^{6}$ This is why Nuorteva's work in the United States in 1918 has to be regarded as one of the early steps toward the establishment of Soviet Russia's delegation in the United States. This becomes apparent in, for example, the requests made by United States officials to Nuorteva for information about the situation in Russia rather than Finland. ${ }^{7}$ The conclusion regarding the importance of Santeri Nuorteva's activities, drawn by the Lusk Committee of New York State, which studied radical activities, appears to be accurate: the Finnish and Russian revolutions were related. When the Reds took power in Finland, the possibilities for the Bolsheviks in the United States to make propaganda for their cause were immediately enhanced. ${ }^{8}$

When we examine Santeri Nuorteva's ideological development, we find that even if he was a radical socialist, in Finland he had displayed certain features which connect him with the revisionists. He emphasized that workers should use all possibilities, including cooperation with the bourgeois groups, to improve the lot of the lower classes or in the fight 
against Tsarist pressure. In addition, while in the United States he was attacked by the extreme radicals of the Finnish Socialist Federation, by those who were attached to the Industrial Workers of the World, the IWW. They accused him of being too cooperative with the ,bourgeoisie (\&nd the »old fashioned «American Federation of Labor, the AFofL. The fact is that Nuorteva for a short period worked as an organizer for the Shingle Weavers' Union on the West Coast (member of the AFofL). He also incurred the wrath of the Finnish IWW-supporters when he strongly condemned the unionism presented by the IWW.

From 1912 to 1917 Nuorteva can be defined as a social democrat. However, after the 1917 October revolution he increasingly turned to the left. He finally broke with the Social Democrats over his admiration for the Russian revolution, his work for Red Finland in the United States, and his willingness to propagandize for the Bolsheviks. Another important factor which separated Nuorteva from Finnish-American and American Social Democrats was his attitude towards the Communist International, or the Comintem, which was formed in Moscow in the spring of 1919. The Social Democrats were not willing to follow the orders issued by the Comintern, whereas the Communists were.

When the American communist movement was born during the years after the October revolution. Finnish-Americans were not at the forefront of the new movement. The Finnish Socialist Federation with its more than 10.000 members was very cautious in their relations with the different factions within American socialism. Government pressure also made the Finns cautious.

When American socialists formed the Communist Party of America and the Communist Labor Party in the fall of 1919, the FSF did not go along with either faction. The growing anti-radical government forced the communist parties underground. With the reduced tensions that accompanied the legalization of the communist party, the Workers Party of America was created in 1921, and the Finns became the largest nationality group in it. In the early 1920's the radical Finns -- the FSF had been split in the process - with more than 6000 members constituted more than $40 \%$ of the membership of the Workers Party, which totaled about 12-15000 members. ${ }^{9}$

It seems that Santeri Nuorteva himself was not very actively involved in the ideological battles of these years - at least there is not much evidence of this. He was above all the propagandist of the Bolsheviks, engaged in diplomatic and,commercial work for the Soviets. Nuorteva was the person who defended Soviet Russia primarily because it was the first "workers' states." 
It is said that Nuorteva was one of the most important figures in the formation of the American communist movement. ${ }^{10}$ But even in his short autobiography, Nuorteva does not say much about his role in the rising American communist movement, beyond mentioning he worked actively for the radical line in the Finnish Socialist Federation." Nuorteva's reputation as a radical and a communist has to be seen as a consequence of the work he did in the Finnish Information Bureau and for the Bolshevik government. In this connection he even attracted the attention of the Military Intelligence. They sent agents to follow him and to report on his activities. His name was mentioned in connection with Morris Hillquit, John Reed, and leftist editors like Eaikrnonn McAlpine, Gregory Weinstein and Louis C. Fraina. There are a number of very dramatic reports accusing him of importing revolution into the United States, of being "an agitator of the extreme type " and sin no way a friend to the best interests « of the United States. ${ }^{12}$ In another report from August 30, 1918, the Military Intelligence agent Julius Wulpert wrote the following from the Socialist Party meeting in Chicago: ${ }^{13}$

. . . while there was nothing anti-American in his speech, his [Santeri Nuorteva] care in choosing his words was noticeable and several questions propounded to him on American diplomacy or government he refused to answer or give an opinion . . .

Subject is a socialist propagandist and a shrewd diplomat. He has called on Mr. Miles of the State Department in Washington, and asked for the assistance of this government, pledging an anti-German policy on behalf of the Red Guard of whom he claims to be accredited agent . . .

The summary of the case of Santeri Nuorteva by the Military Intelligence, a total of more than 60 pages, contains much detailed information, and points to Nuorteva as one of the central figures in the formation of the American communist parties in 1919. It also claims that Nuorteva and Martens, who was named the representative of Soviet Russia in the United States in 1919, had used large amounts of money to import revolution into America. According to the summary Santeri Nuorteva was nominated an honorary member of the American Communist Labor Party together with some American radicals like Eugene V. Debs. ${ }^{14}$

The reports and letters which arrived at the Military Intelligence offices were often a combination of facts and imagination. Much erroneous information was received from the rightist Finnish-Americans or rightwing socialists who were the senemies« of the communists and the radicals. They often wanted to discredit Nuorteva and the radical line of the Finnish-American socialists. ${ }^{15}$

More suspicions were aroused towards Nuorteva when his work for Soviet Russia was made official. Some attempts to obtain recognition for Soviet Russia had been made already at the end of 1917 , with the 
establishment of an organization named Friends of the Russian Revolution, also known as the Friends of New Russia. Its purpose was to promote the peace conditions presented by the Bolsheviks. At the beginning of 1918, the American Bolshevik Bureau of Information was founded, which in a sense was the predecessor of Martens' bureau. Its founders were purely »American « radicals, willing to help stabilize the young Soviet state. ${ }^{16}$

The name of Santeri Nuorteva does not occur in connection with the above mentioned organizations. Instead, he was one of the leaders of the Soviet Russian Recognition League, established in the middle of 1918. Its president was Alexander Trachtenberg, a well known emigrant and leftist. Nuorteva himself claims to have established the League together with Gregory Weinstein, Juri Lomonossow and other radicals working in America. ${ }^{17}$

In addition, before the creation of Martens' office, certain other organizations promoting ties with Soviet Russia were operating in the United States. One of them was the Friends of Soviet Russia, which aimed at getting material help for Russia.

More or less unofficially, Nuorteva used the Finnish Information Bureau to work for Soviet Russia, as we have noted. In his autobiography Nuorteva states that he and Gregory Weinstein established the new Soviet Russian Information Bureau while working for the Finnish Information Bureau. There they argued against intervention in Russia and for the recognition of the Soviet state. ${ }^{18}$ It seems at times difficult to determine which of the various organizations was named Martens' bureau at the beginning of 1919, or was the Soviet Russian Information Bureau a new one, without a predecessor? Perhaps the last alternative is the right one. Thus, we may suppose that Nuorteva's and other radicals' work and organizations formed the basis on which Martens' bureau was built. For example, the Finnish Information Bureau was gradually closing its doors, and finally its staff moved to the Soviet Russian Information Bureau and a new address.

Nuorteva's role in the formation of the Soviet Bureau is not clear. He appears to have been quite an important figure in the process, even if Martens' role is dominant in Soviet historiography. This is apparent in the works of Tarle and Evgen'ev and Sapik. ${ }^{19}$

However, it must be emphasized that the developments before the foundation of the Soviet Russian Information Bureau include a great deal of voluntary work. Nuorteva and other persons worked voluntarily for Soviet Russia. They financed their activities from donations, lecture fees or rewards, and payments for "other kinds of jobs. $2^{20}$ During this 
voluntary phase Santeri Nuorteva had a very important role in the propaganda work. This is reflected in e.g. the words of Theodore Draper, who says that Nuorteva was the most prominent spokesman for the Bolsheviks in the United States before the foundation of the Soviet bureau. ${ }^{21}$

The Bolsheviks appear to have had difficulties in establishing relations with the Americans. Actually, Maxin Litvinov was in June 1918 nominated as their plenipotentiary in the United States. He did not arrive in the country, but at the beginning of 1919 the Bolshevik regime nominated Ludvig C.A.K. Martens as their representative and as the head of the new Soviet Russian Information Bureau. He presented his credentials in Washington on March 18, 1919, in a document which was also signed by Santero Nuorteva, the secretary of his bureau. Attached was a long description of the conditions in Russia, signed by Martens and Nuorteva. ${ }^{22}$ Apparently it was written by the latter.

The nomination of Martens actually marked the stabilization of the work by Nuorteva and others. Martens (1875-1948) was an old revolutionary who had come to America in 1916. He had worked as the vicechairman of Weinberg \& Posner, a machinery firm, when he was called to the service of the Bolshevik regime. Martens continued his activities in the bureau until the beginning of 1921, when he returned to Russia and the activities of the bureau were stopped. In December 1920 Martens' deportation was ordered but the actual expulsion was not carried out because of the desire not to bring the existing American-Soviet relations to a crisis. ${ }^{23}$ The United States government did not actually recognize the Bolshevik government until 1933.

The office of the Soviet Russian Information Bureau was located in New York at the World Tower Building, 110 W.40 Street. Placing the office in New York City is proof, according to Anthony C. Sutton, that it was intended more for the creation of commercial than diplomatic relations with the United s t a t e The-climate for the work of the bureau was not good. Because of the tension in the country, the fear of Bolsheviks, radicals, aliens, etc., its activities were closely monitored. The leading men of the bureau, Martens and Nuorteva, were called to testify before the Senate subcommittee that was investigating radical activities in the United States. In 1919 the office was raided and its materials confiscated by the Lusk Committee of the State of New York.

Anyway, the Soviet Bureau at the beginning of 1919 consisted of almost forty persons, although many of them seem to have been only nominally associated. The head was Martens; the "chief of the bureau" was listed as Gregory Weinstein and the secretary of the bureau as San- 
teri Nuorteva. Nuorteva also had a personal secretary, Dorotha Keen, who had worked in the Finnish Information Bureau. According to the lists preserved from the bureau, it was organized into commercial, technical, medical, economical-statistical, editorial, legal and information departments. Each of these had several workers. Included among the personnel were, e.g., the above mentioned lawyer and socialist leader Morris Hillquit as well as the well known economist Isaac A. Hourwich. Nuorteva was ranked second to Martens.

Nuorteva's work consisted mostly of giving information to the American press and government officials. A good account of his activities is given in the pages of the Weekly Bulletin of the Bureau of Information of Soviet Russia, which appeared in New York from the spring of 1919. It was soon followed by a periodical called Soviet Russia. Both of these included descriptions of the diplomatic efforts of the Bolsheviks, documents from Soviet Russia, descriptions of the life of ordinary people in Russia, and facts about commercial relations between Soviet Russia and the United States.

In addition to the information services, Nuorteva also took care of the diplomatic work of the bureau. On several occasions he was even called the shead of the diplomatic department. $2^{25}$ One of his most important and peculiar attempts in this field was the effort to help the Paris peace conference of 1919 establish a contact with Lenin and his government. There was the problem in Paris of how to deal with intervention in Russia, as well as how to deal with the warring groups there. Woodrow Wilson made an effort to bring the opposing factions to the negotiation table in Prinkipo, on the Sea of Marmara. He failed, as only the Bolsheviks agreed to come. ${ }^{26}$

Nuorteva appears to have had a role in this process - or at least he tried to have one. According to the papers preserved by the Department of State, Nuorteva contacted the legal adviser of the large Hearst company, Mr. Granville S. MacFarland, and with his help was able to meet the under secretary of state, Frank Polk. Nuorteva suggested that he send a wire to Lenin through American officials in Paris, to make sure that the Bolsheviks would send delegates to the proposed Prinkipo conference. It is not clear if Nuorteva's activities had any real effect. According to Anthony C. Sutton, Nuorteva's wire was not sent to Lenin. ${ }^{27}$ But perhaps Nuorteva still played a role in the process, since the Bolsheviks did agree to come to Prinkipo.

Efforts to promote commercial relations between Soviet Russia and the United States appear to have been of great importance for the Soviet Russian Information Bureau. Martens himself stated that the pro- 
motion of commercial relations was the primary concern of the bureau. ${ }^{28}$ This strategy was based on a realistic analysis of attitudes in the United States: it was clearly very difficult for the Bolshevik regime to gain recognition by the United States government. It was easier to develop commercial contacts, and by starting there, it might be possible to work towards diplomatic recognition.

Trade relations with foreign countries in the Western World were of primary importance for the Soviets. After the October revolution it was important to stabilize and stimulate economic life in Russia. The Soviets had suffered enormous losses both in the World War and in the chaos of Civil War and foreign intervention. Practically everything was needed.

According to the studies by Anthony C. Sutton, American business circles had been in contact with the Russian revolutionaries even before the actual revolution. Later, there were several companies which traded extensively and made agreements with Soviet Russian enterprises - for example, in 1919 for more than \$20 million worth of machinery, foodstuffs, clothes etc. ${ }^{29}$

Santeri Nuorteva, unlike Martens, hardly had any major commercial experience, but he engaged in business relations and referred to himself as the ))purchasingdirector « of Soviet Russia. In the materials confiscated by the Lusk Committee there is correspondence from the Soviet Russian Bureau of Information to about one thousand American business enterprises. Nuorteva also claimed to have been in contact with some 500 businessmen..$^{30}$ According to Soviet historian Leo Suni, Martens and Nuorteva were an object of great interest for the capitalist business world. This was quite natural since western businessmen saw great possibilities in the reopening of the Russian market. ${ }^{31}$

As it is well known, the Russian revolutionaries tried to finance their activities abroad using funds accumulated by the Tsarist regime. It had made big deposits in foreign banks and now the Bolshevik government tried to confiscate them by claiming to be the legal government of Russia. The Bolsheviks also obtained cash by selling off the valuables of the Tsar and his family which had fallen into their hands during the course of the revolution. Therefore, even Martens' and Nourteva's bureau in the United States appears to have had quite a lot of money at their disposal. If we can believe the announcement made by Martens in March 1919 , the Bolsheviks had decided to use \$200 million which were deposited in the banks of Western Europe and the United States »during the first stages of commercial relations « with the Western countries. ${ }^{32}$ From the beginning of 1920 Russian money and valuables were transported 
via Sweden and Norway to the West..$^{34}$ The large amounts Martens mentioned are also understandable as sums to lure the American public and the business world.

Even Santeri Nuorteva appears to have received money through these channels, as indicated by the infamous case of Carl Sandburg, about which a large amount of correspondence between the United States government officials and Nuorteva has been preserved. Carl Sandburg was known for his socialist sympathies and when he returned from Oslo to America at the end of 1918 he was given a cheque of $\$ 10,000$ to be given to Nuorteva. However, at the port of New York he was thoroughly searched and the cheque confiscated. ${ }^{35}$ Nuorteva later tried to recover the money, but in vain.

Not all Bolshevik sympathizers in the United States approved of the commercial role of the Soviet Russian Information Bureau. This is why Martens and Nuorteva appear to have had some difficulties with them, and this is why even the Comintern had to defend the Soviet Bureau's work. ${ }^{35}$ The anti-radical sentiments in America also caused difficulties like the raid of the bureau in 1919 and the investigations of the bureau's activities. This is why Santeri Nuorteva had to leave the country in the summer of 1920 and Martens followed in early 1921.

Furnished with a diplomatic passport by Ludvig Martens, Nuorteva reached Canada in June 1920. There his task was to contact businessmen who had shown a keen interest in the great markets that were now opening up in Soviet Russia. But the Red Scare was having its effect in Canada, too, and questions began to be raised in Parliament about the way in which Canadian-Soviet trade was being handled, and about Nugrteva. The latter had now, however, found it wiser to leave for Eng- • land - which was probably the ultimate destination he had had in mind when he departed from the United States. ${ }^{36}$

Towards the end of June 1920 this »Red Diplomat" arrived in England where he intended to work for the Soviet Russian commercial agency in London. The head of this agency was the old Bolshevik Leonid Krasin, but Nuorteva only managed to work for him for a very brief period. Scotland Yard had kept a close watch on Nuorteva's activities, and it was alleged that he established contacts with English leftwing radicals. He was arrested and his deportation was planned; particularly in view of the information received from the United States, he was regarded as extremely dangerous. The arrest of Nuorteva caused a great sensation in England, and questions were put to the Government in Parliament about his fate and the reasons for his arrest. The news spread quickly to Finland and Soviet Russia. A sharply-worded demand 
for Nuorteva's release was sent by the Soviet Commissar for Foreign Affairs, Chicherin. The British now had to consider where to deport him. They decided on Soviet Russia, a country to which Nuorteva himself wanted to go. He did not want to be returned to Finland, fearing that he would be arrested there, and the United States refused absolutely to allow him to return. The actual deportation was a farce. The British despatched Nuorteva to Soviet Russia by way of Denmark, but the Danes refused to let him into the country, and he was returned to England. This provoked further public controversy, and the next step was to send him on a British warship to Tallin, where he arrived at the end of July 1920. The British Government and the Admiralty subsequently became the butt of criticism for having devised so expensive a solution.

The conclusion has to be drawn that the British wanted to get rid of Nuorteva at whatever cost. Their fear of him did not lack foundation, for in the United States he had shown himself to be a most effective propagandist for the Bolsheviks, as well as a skilful creator of contacts. With his linguistic capabilities, Nuorteva was able to move without any great difficulty in international circles. On the other hand the fear of Communism that prevailed in the West easily gave rise to exaggerated opinions about the danger of a man like Nuorteva. The improvement of trade relations could still be seen as an attempt to implant Communist beliefs in the world outside Soviet Russia. It certainly seems to have been the case that among Nuorteva's duties was that of maintaining contacts with left-wing groups in different countries; this is indicated by his work for the Comintern.

In Soviet Russia Nuorteva was given a post in the Commissariat for Foreign Affairs. He became the head of a section whose primary concern was the Anglo-Saxon countries. With the limited material available, it has not been possible to make a close study of his work there. Nevertheless it is clear that Nuorteva enjoyed the respect of Western diplomats stationed in Moscow. On the other hand, his radical reputation haunted him abroad, as evidenced by the unsuccessful attempts to send him to Canada and Norway on commercial (and political?)missions. In the autumn of 1924 Nuorteva was sent to Stockholm to be head of the local branch of the Soviet Information Bureau, Rosta. He nevertheless had to be recalled immediately to Moscow at the request of the Swedish Government, for the Swedes strongly suspected that Nuorteva had gotten involved in the country's internal affairs and that he had in particular been in touch with the local Communists.

Once it appeared that no suitable tasks could be found for Nuorteva in Moscow, he was transferred to Soviet Karelia. There he worked as a 
commissar for educational work and in quite important parts of the administration. Before his death he occupied for several years the highest post in Soviet Karelia: he was chairman of the executive committee, in other words, president of Soviet Karelia.

Santeri Nuorteva's restless and eventful life came to a close in 1929. It is a matter of sheer guesswork as to whether Nuorteva, who had known Lenin since the year 1907 when he helped him on his flight abroad through Finland, would have become a successful politician of the ilk of Otto Wille Kuusinen. He might, on the other hand, have been purged during the period of the Stalinist oppression in the 30's, a fate that did indeed befall many other Finns who had moved to the Soviet Union. Doubts about Nuorteva's political position were frequently expressed during his lifetime - even in Finland he had engaged in controversy with Kuusinen about the legitimacy of reformism. In the United States, radicals had criticised him for supporting »the bourgeois working-class movement« (i.e. the AFofL). When Nuorteva was arrested in Soviet Russia in the spring of 1921 and kept in prison for about ten months, speculation arose in the West that he had fallen into disfavour precisely as a consequence of ideological errors. A more detailed study of this aspect of his career - as with many other of the vicissitudes of his life would seem to be possible only when the archives of the Communist Party of the Soviet Union are opened to researchers.

\section{NOTES}

1. The author of this article has written the biographical study »Santeri Nuorteva - kansainvalinensuomalainen, "which will be published by Suomen Historiallinen Seura, The Historical Society of Finland, in their series Historiallisia Tutkimuksia

2. For an evaluation of the reliability of the Military Intelligence reports regarding the Finnish-American socialists, see Auvo Kostiainen, "Turbulent Times: The Last Years of Santeri Nuorteva in America, 1918-1920, «in Finnish-Americana, III (1980), esp pp.43-50.

3. See, e.g. V.V. (Vaino Voionmaa), "Santeri Nuorteva," in Kansallinen elämäkerrasto, IV (Porvoo, 1932), pp. 234-235, and Vystavka A F Nuorteva Kratki ukazatel. Nayttely Santerl Nuortevan muistolle. Lyhyt opas, S.A. Makar'ev, ed. Transl. into Finnish by Hanna Karhinen. Petrozavodsk 1929. See also Theodore Draper, The Roots of American Communzsm (New York, 1963), pp. $78,107,109,162$, ff.

4. Materials on Nuorteva's activities are found e.g. in the Lusk Committee papers at the New York State Library, State Archives, Albany, N.Y., part. box 11; and Records of the War Department, General of Special Staffs. Military Intelligence Office Correspondence, National Archives. Microfilm in the possession of the writer. See also, Auvo Kostiainen, »'Punaisen Suomen' edustus Yhdysvalloissa vuonna 1918, "in Turun Historiallinen Arkzsto XXVII (1972), p. 90.

5. See »Suuret kansanjoukot New Yorkissa tervehtivat Suomen työväenhallitusta, « Raivaaja, May 13, 1918. 
6. See the report by Nuorteva in Kostiainen, 1972, pp. 100-102.

7. Ibid. and materials in folder 42 , box 11 , Lusk papers.

8. Reuolutionay Radicalism. Its History, Purpose and Tactics with an Exposition and Discussion of the Steps Being Taken and Required to Curb It. Being the Joint Legislative Committee Investigating Seditious Activities. Filed April 24, 1920, in the State of New York, (Albany, N.Y., 1920), Part 1, vol. 1, p. 631.

9. About the birth and early years of the Finnish-American communist movement, see Auvo Kostiainen, The Forging of Finnish-American Communism, 1917-1924. A Study in Ethnic Radicalism (Annales Universitatis Turkuensis, ser. B, part 147, Turku 1978), esp. pp. 137-158.

10. Ibid., p. $80 \mathrm{ff}$.

11. See Nuortevais Avtobiografija, at the Leningrad party archives.

12. Intelligence officer report from Nov. 24, 919, quoted also in Kostiainen, 1980, p. 48.

13. Quoted from, ibid., p. 44.

14. Synopsis of the case of Santeri Nuorteva in Military Intelligence Office Correspondence, NA.

15. See Kostiainen, 1980 , pp. 45, 48-49.

16. Draper, 1963, pp. 106-107.

17. Ibid., p. 109, and "Soviet Russian Recognition League, " folder 14, box 13, Lusk papers.

18. Nuorteva, Avtobiografija.

19. See G. Ja. Tarle, Drużja strany sovetov. Učastie zarubeznyh trudjascihsja vvosstanouleniinarodnogo hozjajstua SSSR v 1920-1925 gg. (Moscow, 1968), e.g. p. 24, and the biography of Martens, G. Evgen'ev and B. Sapik, Revoljucioner, diplomat, ucenyj (O.L.K. Martense) Moscow, 1960).

20. Nuorteva, Avtobiografija.

21. Draper, 1963, p., 109.

22. Papers Relating to the Foreign Relations of the United States 1919, Russia (Washington, 1937), pp. 133-141.

23. E.G., ibid., pp. 146-149 and Robert Paul Browder, The Origins of SovietAmerican Diplomacy (Princeton, N.J., 1953), pp. 14-16.

24. Anthony C. Sutton, Wall Street and the Bolshevik Revolution (New Rochelle, N.Y., 1974), p. 114.

25. See, e.g. the Synopsis of the case of Santeri Nuorteva.

26. Seth P. Tillman, Anglo-American Relations at the Paris Peace Conference of 1919 (Princeton, N.J., 1961), pp. 137-139.

27. Sutton, 1974, p. 114; see also memorandum by Polk on Jan. 29, 1919. Records of the Dept. of State Relating to Internal Affairs of Russia and Soviet Union, 1910-1929, group 861.00/3875, NA.

28. See Weekly Bulletin of the Bureau of Information of Soviet Russia, March 24, 1919; cf. Tarle, 1968, pp. 70-71.

29. Sutton, 1974, pp. 58-63, 158.

30. Cf. New York Times, June 21, 1919.

31. Leo Suni, "Huomattava kumousmies (Santeri Nuortevan syntymän 100 -vuotispäiväksi), « Neuvosto-Karjala, June 24, 1981.

32. See Weekly Bulletin, March 24, 1919.

33. Sutton, 1974, p. 159.

34. Materials on this case is found, e.g. in the papers of the Military Intelligence Office papers.

35. See Irving Howe and Lewis Coser, with the assistence of Julius Jacobson, The American Communist Party. A Critical History, 2nd printing (New York, 1962), p. 62.

36. Information about Nourteva's later phases is based on the biography written by the author of this article, see note 1 . 